\title{
The Francophone Writer at the Crossroads of Languages
}

Peter W. VAKUNTA

Nazi Boni's Crépuscule des temps anciens is rich in several respects but the quality that captures the reader's attention the most is the writer's narrative style - the manner in which he indigenizes the French language to express Bwamu sociolinguistic reality. Boni makes ingenious use of language in an attempt to adapt French to the worldview, sensibilities and imagination of his native language. As Millogo puts it: "L'auteur opère un choix bien déterminé et bien frappant dans le matériau linguistique bwa...." (32). Though writing in French, Boni manages to produce a text that could be described as an indigenous language text written in French. By and large, he succeeds in doing this by having recourse to the technique of indigenization by which he imbues his text with Africanisms which add local color to the text and ascribe new significations to French words. Indigenization in this context deals with translating the worldview and imagination of Africans into a European language (Zabus, 1991, p. 23 ). This strategy fulfills the critical function of bridging cultural gaps in a multilingual communication context where indigenous and foreign languages jostle for space. As Gassama points out:

Il y a, en effet dans nos langues, des termes intraduisibles en français; les termes français correspondants ne satisfont pas toujours le romancier: si le terme français parvient à transmettre 
le contenu notionnel, il sacrifie les valeurs évocatrices du terme africain. (226)

Boni resorts to Bwa terms and expressions to fill these apparent gaps. For instance, he uses the word "Dô" or rite of passage, which could be translated as "rite" in French. However, he refrains from using the French word because the extra-linguistic connotations associated with the "Dô" rite of passage (e.g., social rank of the initiates, age disparity, etc) implied in the indigenous language term would not be conveyed in the French term. On this count, Boni deems it necessary to transpose the Bwa word into French. Indigenization occurs in the text through the transposition of vernacular words into the narrative as the following example shows: "Vous savez qu'on n'affronte pas ces épreuves en nombre impair sous peine de voir le plus jeune de la promotion avalé par le Dô" (113). In Bwamu culture, when the youngest participant in a rite of passage dies, it is said that s/he has been "avalé par le "Dô." Boni indigenizes the French word "avaler" by giving it a culture-specific signification. By having recourse to the technique of semantic shift, he ascribes a new meaning to this French word. In this context the word connotes "mourir". The narrator provides a succinct definition of the word "Dô" in the following excerpt: "Bien que Térhé fut le chef de file, il revenait à $B$ 'eeni de prendre la parole en sa qualité de fils du détenteur du fétiche des cultures: le Dô" (110). The term "Dô" is translated into French as "fétiche des cultures." The writer avoids a literal translation of the word, opting for a paraphrase. Characters associated with this rite are described using Bwa words namely, "yenissa" (118) [initiates], "bruwa" (111) [non-initiates] and "pamma" (111) [initiates in power]. The word "Dô" occurs repeatedly in the narrative and underscores the importance of this cultural practice for the Bwamu who perceive it as a "passation des pouvoirs" (163) or transfer of power. On the occasion of the "Dô" the "yenissa" are expected to hand over power to the "bruwa." Linguistic innovation plays a significant role throughout the novel - serving as a vehicle for the transposition of culture-bound concepts into the European language.

The presence of several indigenous terms and expressions in Crépuscule des temps anciens is an indication that Boni strives to bridge linguistic and cultural gaps in the act of storytelling. In doing so, he transgresses the normative canons of French grammar. All too often, he resorts to the use of native-tongue turns of phrase which may disconcert the Metropolitan speaker of French as seen in the following example: "Des générations étaient nées, avaient fait leur soleil et disparu" (19). In this excerpt, the word "soleil" acquires a new signification. In Bwamu, the word "soleil" 
refers to "epoch" or "era." Thus, the expression "avaient fait leur soleil" could be translated as "had seen their suns." Boni indigenizes the French language for the purpose of self-representation.

Literary indigenization fulfills didactic functions in the novel as well. Bwa metaphorical expressions present the reader with essential information on the belief systems of the Bwamu. For example, Térhé uses a proverbial expression to shed light on Bwa belief in common sense: "A refouler trop loin le crapaud on arrive à le remettre dans l'eau" (206). This proverb provides useful insight into the mindset of the Bwamu. It also crystallizes Térhé's character by throwing light on his inner-most thoughts and feelings about human relations. Sometimes, Boni uses native-tongue figures of speech for their persuasive value as this example shows: "La sagesse des Anciens nous apprend que Dombeni-Dieu-le-Grand ne crée jamais un oiseau sans l'avoir, au préalable nanti des moyens de trouver sa pittance" (22). This wise saying underlines the Bwa belief in the omnipotence of God.

Crépuscule des temps anciens is a classic example of contemporary African prose literature that underscores the cultural specificity of the context of creative writing as seen in the act of naming. Onomastics bears a stamp of cultural identity in the narrative. As Washington observes, "At birth, the child receives a name which is in direct relation to life forces associated with his clan's frame of reference. The name is conceived of as designating a real ontological individuality and expresses the very nature of the person" (cited in Julien 119). Names are meaningful appellations whose connotations may remain oblique to readers who do not belong in the cultures in which such names are used. Like Kourouma (1970), Boni uses the art of naming to communicate significant cultural messages. Most of the names he uses are of Bwa origin: Térhé, Kya, Lowan, Hadonfi, Hakani, Gnassan, Nazouko, etc. Proper names are used in several ways and for different purposes. Some serve as comments on the name-bearers. For example, Kya is translated as bero, that is to say, someone who kills with impunity. It is may be difficult to find equivalents for these names in European languages on account of disparities based on lived experiences. For example, the white colonizers are called "Nansara" meaning "inhabitants of the sky" or "sky people" on account of their association with the airplane as the following passage shows: "Il parait que la cornubation de Bonikuy a reçu la visite d'un homme phénomenal descendu du ciel: un homme tout rouge, avec de longs cheveux noirs, en brousailles: un Nansara"(215). Throughout the narrative, the word "nansara" is used as a synonym for "ennemi" because the Bwamu could not "tolérer que 
les Nansarawa après s'être insidieusement installés sur la 'Terre de leurs Ancêtres', se comportassent en maîtres, forts de l'appui de certains renégats autochtones" (222).

Boni also resorts to indigenous language words to categorize fauna as seen in this example: "Sa boueuse excellence $M b$ 'woa Gnoundjoa, le 'cheval aquatique "dont le ventre traîne à terre, y allait siester dans la fraîcheur marécageusse après avoir fauché le riz plantureux et les herbes rivulaires" (25). The term Mb'woa Gnoundjoa is the Bwamu term for "hippopotamus." In some instances, names translate respect due to age. For example, the title "Mb'woa" is given to people of a certain age. It could be translated as "grand-père" or "ancêtre" (Millogo 261). For instance, Mb'woa Gnassan is called "knife-bearer" in the following passage: "On commençait à s'impatienter quand arriva, suivi de son suppléant, le 'porte couteau', et de son héraut, un nonagénaire grand, nerveux et sec. Un murmure de respect parcourut la foule: Mb'woa Gnassan!!! Mb'woa Gnassan!!!"(42). It is clear from this passage that Mb'woa Gnassan is a noble - he has a retinue, comprised of a messenger and lieutenant. Above all, he is given the honorific title "knife-bearer," which ranks him among the privileged in the community. This is cultural information that Boni transposes into French by having recourse to the device of indigenization. Sometimes, Boni gives the name "Mb'woa" to astral bodies. For example, he refers to the moon as "Mb'woa P'hihoun" as the following sentence shows: "Emmitouflée dans son pagne de lumière Mb'woa P'hihoun, la Lune, passait en revue l'armée des étioles" (35). The personification of the moon in this passage is culturally significant that given the Bwamu believe that people's lives are controlled by celestial bodies. The attribution of human qualities to astral bodies suggests that the Bwamu maintain a symbiotic relationship with these bodies. Names, therefore, express both cosmological and ontological beliefs of the Bwamu. These examples go to show that Crépuscule des temps anciens could be considered an ethnographic novel on account of the cultural functions Boni assigns to language.

The most impressive quality of this text is the novelist's experimentation with language. His success resides in his ability to fashion out a hybrid language through the fusion of Bwa and French terns and expressions. As Millogo puts it, "L'auteur chante sa culture dans une oeuvre d'expression française certes, mais savamment et artistiquement construite à partir des langues et des sensibilités bwaba et française" (96). The "bwamufication"। of French in this text is achieved mainly through the technique of semantic shifts, a process whereby "[...] la signification des mots bwamu est 
systématiquement donnée en français selon les procédures nombreuses et variés de traduction, de reformulation et de construction de contextes de significations" (Millogo 100). Put differently, Boni employs African words and expressions bearing extended meanings.

Relexification enables him to play the role of a 'culture broker'. In other words, he succeeds in explaining Bwa cultural concepts in a language that did not create those concepts. The entire novel reflects his extremely rich knowledge of Bwa oral traditions. "Bwamufication" endows his text with a character that helps maintain a close bond between traditional verbal arts and the written word. As Ladmiral puts it, this writing technique " $[\ldots]$ produit un texte-cible sémantiquement, stylistiquement, poétiquement, rythmiquement, culturellement, pragmatiquement [...] équivalent au texte source" (cited in Millogo 60). Various forms of traditional verbal arts, including chants and songs are used by Boni as anchorage for his writing. It is perhaps for this very reason that his novel could be described as a kind of audible palimpsest. Genette argues that a text like Boni's could be seen as "[...] la vieille image du palimpseste, où l'on voit, sur le même parchemin, un texte superposé à un autre qu'il ne dissimule pas tout à fait, mais qu'il laisse voir par transparence"'(41). Thus the palimpsest is an attempt at getting rid of that which pre-existed in an attempt to write anew. Boni's desire to construct a French language text with a Bwamu cultural substratum remains visible throughout the narrative as seen in his use of ideophones

Bwa ideophonic expressions are transposed into the novel in an attempt to imbue the text with expressive vividness. Ideophones convey ideas relating to sounds, color, taste, and emotions as seen in this passage: "Térhé, tu es le dieu de la danse. Quand brille l'éclair, les hanwa s'écrient: 'Weeyo!' se tournent vers toi et te supplient: 'Beau gars, donne la réplique, danse et brille après l'éclair, comme un couteau d'argent [...]" (148). The expression 'Weeyo!' is an interjection signifying supplication. The hanwa (women) are entreating the formidable dancer, Térhé, to outperform the others. The expression that conveys the strongest feeling of emotion in this text, however, is wéée! This cry of desperation from a cuckolded husband is remarkable in the following passage: "Alors le malheureux conjoint se rendit compte de l'horreur de sa situation et poussa un wééé de désespoir, car il était à la merci de son antagoniste" (69). The ideophone "wéée" modifies the verb "poussa," giving it a specific meaning. These interjections serve as excellent examples of the indigenization process that is taking place in the text. The writer interpolates Bwa words into French and expresses the feelings of the Bwamu in this European language. $\mathrm{He}$ 
employs indigenous language interjections to imprint his text with the speech mannerisms of his people.

This switching of codes enables him to give prominence to the Bwa language in his text as the following example lucidly shows: "A chaque cérémonie funéraire, le ti'mbwani commence toujours par évoquer ce souvenir: Bwan-loho Nihi'nlé 'ville de Bwan, mortalité'" (47). Boni juxtaposes Bwa words with their French language translations: "Bwanloho Nihi'nlé" is rendered in French as "ville de Bwan, mortalité". This writing technique is reminiscent of Birago Diop's style in Les contes d'Amadou Koumba (1961). Like Diop, Boni writes: "Je t'écorcherai jusqu'à l'heure où Kobê-le-coq interpellera sa mère. Seule Humu-la-mort m'imposera le silence" (49). The word "Kobê" is the Bwa equivalent of the French word "coq". In a similar vein, the Bwa word "Humu" translates the French word "mort". A critic of Boni's novel may question the rationale behind the simultaneous use of synonymous words. The text is filled with such artful lexical juxtapositions. Sometimes, the writer uses the technique of language mixing to familiarize the reader with the religious beliefs of the Bwamu as this example shows: "Les Nanyê-Kakawa étaient des hommes-génies. Innombrables, ils se montraient uniquement à ceux qu'ils honoraient" (25). By having recourse to the technique of "Bwamufication" Boni transposes Bwa lexes into the French language. As Millogo points out: "Les éléments de la langue bwamu s'incorporent au français par la voie de l'écriture" (41). Lexical reformulation makes this incorporation feasible. Reformulation enables Boni to integrate Bwamu syntactic structures into French as seen in the following sentence: "Son seul nom semait la terreur. Pour inciter les malfaiteurs à parler bwamu, c'est-à-dire franchement pour les contraindre à avouer leurs forfaits, on menaçait d'appeler sur eux la 'sanction de Kya'" (63). The expression "parler bwamu' is a calque on the French expression "parler franchement." Boni restructures hackneyed French expressions to imbue them with new meanings as seen in this example: "Elles resteraient jusqu' aux calendes bwa" (150). The expression "rester jusqu'aux calendes bwa" is a reformulation of the French expression "renvoyer ou remettre aux calendes grecques". Syntactic reformulation may obfuscate comprehension for readers unfamiliar with the Bwa language and culture. To remedy the situation Boni often uses footnotes to shed light on words he suspects may constitute a stumbling block to the reader. Such is the case with the word "kata" which he translates as "lit de bambou ordinairement appelé tara" (51). These examples lend credibility to the claim that Crépuscule des temps anciens is a text steeped in the native culture of its author. 
It should be borne in mind that what Boni does in his text is a far cry from interlingual translation - the matching of lexical items in the source text with equivalent lexical items in the target text. He seeks to achieve intralingual translation, a process that enables him to transpose the worldview and sensibilities of the Bwamu into French. In other words, he expresses himself in a European language but in a manner consonant with the idioms and structure of an African language. In actual fact, what he engages in is communicative translation which enables him to translate not words but the imagination of the Bwamu into the French language. A classic example is the expression "boire à la gourde des fous" used in reference to someone who is mentally deranged as this passage shows: "Mais non! Tu déraisonnes; on dirait que tu as bu à la gourde des fous" (41). The expression "boire à la gourde des fous" is a calque on Bwamu language.

Oftentimes, Boni resorts to the technique of transculturation to underline cultural specificities as seen in this example: "De son côté veillait Gnoundofini, 'dieu de la tête' ou dieu individuel qu'il faut assimiler à l'ange gardien des Mon-père-wa et des Nasamuni-wa (28). In this sentence, the novelist adumbrates the Bwa concept of a "personal god." $\mathrm{He}$ starts off with the vernacular language word "Gnoundofini" but sensing that his non-Bwa readers may have difficulty understanding it, he translates it as "dieu de la tête." Not entirely satisfied with the translation, he renders it as "dieu individual." Of particular importance is Boni's neology in the sentence above. He creates words such as "Mon-père-wa" and "Nasamuni-wa" which he translates in a footnote as "Pères-blancs des missions catholiques" and "pasteurs protestants" (28).

Quite apart from neologisms, Crépuscule des temps anciens abounds with proverbs that illuminate the mindset of Boni's characters as seen in the following example "La lapine ne donne pas le jour à de courtes oreilles" (67). This proverb is used by the narrator to dwell on the comportment of Hakanni who breaks her clay pot when teased about her love for the protagonist, Térhé. Her action is likened to that of her mother who did likewise in her teens. The proverb is meant to translate the standard French expression, "tel père, tel fils." Proverbs do not only convey cultural information; they fulfill a moralizing function as this example illustrates: "Quand un enfant a les mains propres, il prend ses repas dans le cercle des Anciens" (81). The desire to teach is manifest in the novel's preface where Manessy puts emphasis on the "souci didactique" of Nazi Boni (13). Some of the proverbs convey sexual innuendoes as the following example indicates: "Une brise bienfaisante caressait les corps, réveillait 
les sens et décuplait la puissance de l'imagination. N'est-il pas vrai que Yohoun, 'Sanctuaire aux reflets d'argent', s'étiole à l'abri de l'air et de la lumière" (54)? The word "yohoun" is a euphemism for a woman's private parts. Out of fear of hurting the sensibilities of his readers, the novelist opts for what he considers a benign word. This paraphrasing technique enables him to name an object without classifying it. Paraphrases used in this text fulfill three functions - definition, precision and specification. Boni's intention to superimpose his native tongue on French is evident from the translation activity that goes on in the text. There is no easy way of dissociating the use of indigenous words from the thematic importance they convey. Bwa words vie for space with French words, leaving the reader with the impression that Boni is constantly negotiating linguistic and cultural spaces in the act of storytelling. As Sissao aptly puts it: "Cette prise en charge des termes de la langue bwamu, expression d'un ancrage culturel bwa très marqué correspond à des spécificités thématiques" (74). Metaphorical expressions raise ontological questions in the text as the following example lucidly shows: "L'enfant peut toiser la lune, mais pas le soleil" (125). The trope of an imprudent child defying the moon says a lot about the Bwa cosmological belief in symbiotic coexistence between humans and celestial deities in ordinary times and on ceremonial occasions.

The description of ceremonies marking marriage, initiation, birth and death are rendered vivid through the use of appropriate Bwa words and expressions as seen in this example:

Quand la nuit tombait, tout le Bwamu luttait, dansait, chantait en s'accompagnant des tianna, xylophone de paille, des poropinis ou flutes, des wi'zawa ou fifres. La mélodie des kokonis genre de harpes, se mélait à la symphonie de kondios, guitaires à cinq cordes .... Tout jeune homme devait savoir manier avec aisance plusieurs instruments de musique, particulièrement le tian-houn, le kondio, le kokoni, le win'za et toutes les variétés de konkoans ou trompettes. Le tiohoun communément appelé balafon, le donkoho, minuscule tambourin de guerre à la taille de guêpe, le kere 'nko, gigantesque donkolo, le kankan, tambour ventru, le ziri'nko, énorme kankan funéraire, constituaient - et constituent encore [...] des instruments réservés aux chanteurs et compositeurs traditionnels: les kakawa. (30-31)

Although some critics may fault Boni for overloading his text with indigenous language terms (Gassama, 1978, p. 223) it should be noted that indigenization does not constitute an encumbrance to the reader because the writer achieves a smooth transition from the indigenous to the European 
language. The novel seems to owe a lot to the semantic importance of the native tongue words he carefully chooses. For example, themes conveyed through words like "Dombeni", "Yunu" "Dô", "Nansara", and "Bwamu" constitute leitmotifs in the entire narrative. The word "Bwamu", for instance, is a word with multiple but related meanings. "Bwamu", is used in relation to the community of Bwa people, their language, worldview and sensibilities. The term is a hyponym of some keywords in the text, notably "Yunu"and "Dô." The novel could be interpreted as the thematic expansion of these keywords that enable the novelist to accomplish his task of indigenization [a process Zabus defines as: "the writer's attempt at textualizing linguistic differentiation and conveying African concepts, thought patterns and linguistic concepts through the ex-colonizer's language" (23)] as seen in this example: "Un devin, un jour remit au jeune homme un oeuf. Il lui spécifia que cet oeuf contenait sa 'silhouette', c'està-dire son double, plus exactement Mako son âme"(67). Faced with the difficulty of appropriately expressing the concept of "double" in French, the novelist tries to resolve the problem by falling back on the nativetongue word "Mako." His desire to express his Bwa imagination in the French language is achieved though a loan translation which serves as a technique for transplanting indigenous knowledge into a foreign language. Through the mechanism of indigenization Boni is able to appropriate the French language. Occasionally, he reproduces indigenous language terms in French because of their picturesque value as seen in this example: "Un frisson me parcourt le corps. Je serrai instinctivement autour de ma saignée, Yaro, mon gris-gris de chasse" (177). As this sentence indicates, fetishes are part and parcel of the lives of the Bwamu. Each hunter possesses his own fetish. Boni does not provide a physical description of the fetish. He only states that it is a solid object carried by the hunter on his body, adding that there are good and bad fetishes.

Indigenization is accomplished with such dexterity that the reader hardly feels any disjunction in the flow of the narration as the following passage indicates: "Kya était parti armé de son sabre, de son arc, de son woro. Il était parti pour une destination inconnnue. Personne ne s'inquiétait. N'était-il pas un béro"(64)? The word "béro" is brought into the narrative after the writer has shed light on the paraphernalia and attributes of a "béro". Boni spares the reader the trouble of having to read cumbersome definitions of unfamiliar words. Military exploits are not the preserve of natives in this text. The nansarawa too are portrayed as great warriors as this passage shows:

Le thème des conversations fut la 'Force' des Blancs que les Bwawa considéraient comme de mauvais génies descendus du ciel. 
La preuve, soulignaient-ils gravement, ce sont leurs amphores qu'aucune main humaine ne saurait façonner, et surtout leurs Kâayâwa ou canons qui tombent comme Karanvanni et crachent du feu comme le tonnerre. Leurs preinprein - fusil Lebel qui distribue la mort à trois mille enjambées à la ronde" (221). Words like "Kâayâwa", "Karanvanni", and "preinprein" are indigenous words used simultaneously with their French language translations. Boni's text is replete with bilingual constructions like these. He embellishes his text with Bwamu words each time he deems it necessary to do so as this other example shows: "Si j'avais retardé son yumu, ses obsèques, c'était parce qu'il convenait de choisir un moment favorable ... Il faut que son yunu revête une ampleur répondant à son passé de héros" (44). Boni places the word "obsèques" side by side with the Bwa word "yunu" for the purpose of clarity. This technique of interpolation enables him to underscore the cultural backdrop against which his text is written. The word "yumbeni" plays a similar role in the text given the close semantic affinity it has with the word "yunu" as seen in the following sentence: "Il faut que toutes les filles de Bwan, vieilles ou jeunes, mariées à l'extérieur, leurs enfants et les enfants de leurs enfants assistent au Yumbeni de l'Ancêtre Diyioua. Il faut que tout le Bwamu soit "versé' ici" (44). The speech pattern in this example is clearly Bwamu as the expressions "leurs enfants et les enfants de leurs enfants" (grandchildren) and "Il faut que tout le Bwamu soit "versé" testify. As a matter of fact, the village Ancestor Gnassan is appealing to the daughters of Bwamu to come in their numbers to the funeral of their Ancestor, Diyioua. The significance of this appeal becomes all the more evident when Gnassan adumbrates in the following terms: "Ensemble, nous mettons, aujourd'hui, en route pour Nihamboloho, le séjour des morts, un homme aux exploits fabuleux, l'Ancêtre Diyioua"(85). Boni artfully translates the Bwamu word "Nihamboloho" by placing it adjacent to its French language equivalent "le séjour des morts." Thus the writer's endeavor to negotiate linguistic and cultural spaces is evident.

The most striking aspect of Boni's style of writing is his determination to write Bwamu through the medium of French. This technique renders his indigenization process hitch-free as seen in his attempt to shed light on the Bwa concept of 'Lokoré': "Mais que vois-je? Une tourterelle qui tournoie dans la chambre du malade. Makô, l'âme de Térhé a déjà quitté son corps. Térhé n'est plus que sa simple envelope, je veux dire qu'il ne lui reste que Lokoré, la carcasse. Sa 'paille est presque consumée" (240). The Bwa term Lokoré translates the French word "carcasse." By providing a translation, Boni gives the impression that the French language equivalents 
are not rich enough to convey the latent meanings underlying indigenous language terms. The immortality of the spirit is underlined metaphorically via the expression "une tourterelle qui tournoie". The "Africanization" of French in the novel is impressive.

Recourse to "Africanization" as a narrative technique serves as an indication that the matrix of the text is African culture. In fact, throughout the novel, the writer resorts to borrowings from his native culture relating to divinities, rituals, rites and fauna. For example, "Dombeni" [God the Great], "M'Bwoa Samma" [elephant], "Tiohoun" [balafon],"Hunu" [death], "Kobê" [rooster], "Hanwa" [women], "Bawa" [men], "Yunu" [funeral], "Yenissa" [elderly people], "Brawa" [young people], "Mb'woa" [Ancestor], "Dô" [rite of passage], "Nimisis"[ Neveux], and so forth. These examples lend credence to the contention that Crépuscule des temps anciens is a novel calqued on the Bwamu language. To give the reader an insight into the concept of Bwa filial relationships, for example, the writer juxtaposes indigenous and French language words as seen in the following passage:

Les Nimisis ou "Neveux," les enfants des soeurs, c'est-à-dire tous ceux dont les familles maternelles sont originaires de Bwan, ont plein droit de se les approprier. Ils ne peuvent prétendre à l'héritage de leurs oncles, mais en revanche, sont autorisés à rafler leurs biens dans certaines circonstances (74).

The word "Nimisis" is translated as "Neveux." Although Boni endeavors to provide translations for native tongue words to facilitate understanding, the mere insertion of these words into a European language text constitutes an act of subversion in itself. As Kane points out, Nazi Boni is among francophone writers " [...] celui qui témoigne le mieux de la difficulté mais aussi de la volonté d'utiliser une langue qui tente d'exprimer de façon satisfaisante l'imaginaire de son ethnie qu'il entendait valoriser" (80). Boni sets out to write in French but realizing that this European language was inadequate to convey his Bwamu worldview, he deems it necessary to translate his native tongue into French. He exploits the rich traditions of his people to provide a cultural backdrop against which the text is written. For example, marriage is of such critical importance to the Bwamu that he infuses his text with vernacular language terms relating to matrimony as seen in this passage: "Il fallait danser $b a \hat{k} a$, la danse du mariage. Il fallait danser cette victoire, signe avant-courrier de la promotion des jeunes" (130). He explains that the bakka is generally intercepted by ululations called Ha huâaba! Lêlêlêlê (129), or nuptial ululations: During marriage ceremonies girls in their teens execute a lewd dance 
called the yenye: "Yenye, la danse des jeunes filles se déroulait dans une ambiance de vertige" (136).

Boni makes use of indigenous language terms to explain lived experiences that are, perhaps, unknown to the Nansarawa, especially the concept of slavery, known as Wobamu in Bwa language as the passage below illustrates: "Alors les Anciens jurèrent qu'au grand jamais la profanation de la 'Terre des Ancêtres' ne les trouverait ou ne les laisserait vivants. Plutôt Humu-la-Mort que Wobamu-l'esclavage"(233)! The word Wobamu translates "l'esclavage" just as Humu renders "la mort." From the beginning to the end, the narrative is spiced with Bwa terms and expressions. Concerning Boni's recourse to translation as a literary device, Gassama makes the following observation:

Il n'y a pas une seule page de Crépuscule des temps anciens où l'on ne rencontre une expression ou un mot africain ou une tournure de langue maternelle judicieusement ou maladroitement transposée en français. Du point de vue de l'apport de notre littérature romanesque à l'enrichissement de la langue française, Crépuscule des temps anciens est certainement notre roman le plus riche (223).

Boni's choice of words is not gratuitous. As Bonou points out: "C'est un moyen pour démontrer que les langues africaines sont riches et qu'elles permettent d'exprimer toutes les réalités. Ce qui fait l'originalité de Nazi Boni, c'est cette symbiose entre l'oeuvre et les réalités socio-culturelles du milieu" (57). Each term or expression is selected with due regard not only for its expressiveness but also for its appropriateness to the themes and contexts of communication. It is for this reason that Sanwidi contends that "Crépuscule des temps anciens se révèle à la lecture une mine d'une grande richesse [...]" (53) The novel is rich linguistically and aesthetically as the foregoing analysis succinctly illustrates.

The urge to appropriate the language of the ex-colonizer in Crépuscule des temps anciens is non-negligible. The desire to use translation as a writing device is manifest throughout the text. Through the technique of translation, Boni is able to transpose Bwa culinary terms into French as seen in the following passage: "Quel plaisir de se retrouver autour des plats de doro et de sauce épaisse, de pois gras, de mil bouilli brassé à la pâte d'arachide, de gnonkon, mélangé de repasse et de légumes verts cuits à l'étouffée, arrosé de beurre et fortement assaisonné"(37). In this passage, the novelist introduces the reader to two Bwa dishes: "doro", a delicious meal made of millet and "gnonkon" - a dish comprising green vegetables, mixed with butter and spices, generally cooked in a tightly 
shut pot. He adds that a meal of "gnonkon" is never complete until it has been "washed" down with a bowl of locally brewed beer called "gnamu": "Apprêter le fonio, le riz, la farine de mil ou de maïs, préparer en quantité industrielle un gnamu sirupeux — bière de mil qui colle aux lèvres [...]" (53). This passage exposes the reader to three basic Bwa culinary terms - "doro", "gnonkon" and "gnamu". This sort of linguistic innovation accounts for the aesthetic richness of Boni's novel.

In this paper I contend that postcolonial Francophone African literature is characterized by linguistic innovation, a device that enables writers to employ the language of the ex-colonizer to interrogate the hegemony of colonial cultures. By having recourse to the technique of indigenization, Boni calls into question some of the assumptions associated with cultural imperialism, notably the predominance of the French language in Francophone literary discourse. He indigenizes his text by having recourse to appropriation strategies in ways that transgress the canons of standardized French usage. By indigenizing the French language, he creates a hybrid text that demands of its readers to be not just bilingual but also bicultural. A problematizing of language and narrative techniques are central to my reading of Crépuscule des temps anciens. The contextual function of language is critical to the understanding of the novel. There is no doubt that as a creative writer Boni straddles two worlds, constantly negotiating space to wed the French language to the rhythms of African speech. Bestriding two cultural spheres, he is virtually at the crossroads of languages. He cannot be faithful to the one without betraying the other. Like the polygamous husband in a dubious romantic relationship, Boni is obligated to make love with both his "wives" - French and Bwamu.

\section{Note}

1. Interpolation of Bwa language words and expressions into an African text written in a European language.

\section{Works Cited}

Boni, Nazi. Crépuscule des temps anciens. Paris: Présence africaine, 1962. Bonou Boniface. G. "Un Pionnier: Nazi Boni." Notre Librairie 101 (1990):54-57.

Diop, Birago. Les contes d'Amadou-Koumba. Paris: Présence africaine, 1969. 
Gassama, Makhily. Kuma: interrogation sur la littérature nègre de la langue française. Dakar: Les Nouvelles Editions Africaines, 1978 . La langue d'Ahmadou Kourouma ou le français sous le soleil d'Afrique. Paris: Editions Karthala, 1995.

Genette, Gerard. Palimpsestes: la littérature au second degré. Paris: Editions du Seuil, 1982.

Julien, Eileen. African Novels and the question of Orality: Bloomington: Indiana University Press, 1992.

Kourouma, Ahmadou. Les soleils des indépendances. Paris: Editions du Seuil, 1970.

Millogo, Louis. Nazi Boni, premier écrivain du Burkina Faso: La langue bwamu dans Crépuscules des temps anciens. Limoges: Presses Universitaires de Limoges, 2002.

Sandiwi, Hyacinthe. "Depuis le crépuscule des temps anciens : panorama du roman." Notre Llibrairie 101 (1990):48-54.

Sissao, Joseph A. "La question du métissage dans l'écriture du roman burkinabè contemporain." http://etudesafricaines.revues.org/ document 121.html?format=print

Zabus, Chantal. The African Palimpsest: Indigenization of Language in the West African Europhone Novel. Amsterdam: Rodopi, 1991. 